\title{
Kinetics of Saccharomyces cerevisiae Fermentation under Metal Ions Stress during Ethanol Production
}

\author{
Prayooth SAOTHONG ${ }^{1,2}$, Boontiwa NINCHAN ${ }^{1}$, Klanarong SRIROTH ${ }^{1,2}$, \\ Kittipong RATTANAPORN ${ }^{1}$ and Wirat VANICHSRIRATANA ${ }^{1,3, *}$
}

\author{
${ }^{I}$ Department of Biotechnology, Faculty of Agro-industry, Kasetsart University, Bangkok 10900, Thailand \\ ${ }^{2}$ Mitr Phol Innovation \& Research Center, Chaiyaphum 36110, Thailand \\ ${ }^{3}$ Fermentation Technology Research Center, Kasetsart University, Bangkok 10900, Thailand
}

('Corresponding author's e-mail: wirat.v@ku.ac.th)

Received: 11 November 2019, Revised: 8 April 2020, Accepted: 11 May 2020

\begin{abstract}
This research investigated the effects of inorganic compounds or metal ions (calcium ion, $\mathrm{Ca}^{2+}$; potassium ion, $\mathrm{K}^{+}$; magnesium ion, $\mathrm{Mg}^{2+}$ ) on ethanol production efficiency invertase, an enzyme produced by Saccharomyces cerevisiae, in sucrose solution, which was the substrate for yeast fermentation. The results showed that all metal ions (concentration 0.20 and $0.60 \%(\mathrm{w} / \mathrm{v})$ ) acted as inhibitors on invertase activity in the order $\mathrm{Ca}^{2+}>\mathrm{K}^{+}>\mathrm{Mg}^{2+}$. Subsequently, these ions inhibited sugar conversion, reducing sucrose utilization and less glucose and fructose consumption based on the high content of remaining sugars in the culture medium. The reduction of the substrate was due to the consumption and an increased growth rate of $S$. cerevisiae, which all resulted in low efficiency of ethanol production and an increase in glycerol content. The glycerol content was increased due to yeast cells' developed mechanism or adaptation to enhance cell survival following metal ion contamination, especially from $\mathrm{Ca}^{2+}$ and $\mathrm{K}^{+}$; furthermore, the glycerol content significantly increased during the changed conditions, such as when the sugars were nearly all consumed. The kinetic parameters such as specific growth rate $\left(\mu^{-1}\right)$, substrate consumption rate $(\mathrm{Q})$, and ethanol production of the research work were also undertaken. In conclusion, metal ion contamination in the sucrose substrate of yeast fermentation resulted in low efficiency of ethanol production, specific growth rate, and substrate consumption rate decrease with the $\mathrm{Ca}^{2+}$ ion (concentration $0.20-0.60 \%(\mathrm{w} / \mathrm{v})$ ) acting more harshly as an inhibitor of ethanol production than the other ions, particularly where there was a high concentration of contamination.
\end{abstract}

Keywords: Invertase, Molasses, Saccharomyces cerevisiae, Metal ions, Ethanol, Glycerol, Fermentation

\section{Introduction}

The efficiency of ethanol production is dependent on the nutrient in substrates, the optimized conditions of fermentation, microorganisms, and inhibitors. Nowadays, ethanol can be produced from several substrates that are mostly sugar-based crops. Furthermore, the selected substrates for ethanol production are agricultural residues (molasses and cassava chip) and lignocellulosic residues (rice hull, bagasse, and corn stover). Molasses, a by-product generated during the sugar cane refining process, can be used in ethanol production as it still contains 50 - $60 \%$ sugar. Besides sugar, sugarcane molasses also contains amino acids and minerals such as potassium $0.04-0.90 \%(\mathrm{w} / \mathrm{v})$, calcium $0.02-0.75 \%(\mathrm{w} / \mathrm{v})$, and magnesium $0.01-0.61 \%(\mathrm{w} / \mathrm{v})$ [1-4]. Based on a range of metal ions that were observed and recorded, $0.20-0.60 \%(\mathrm{w} / \mathrm{v})$ is an appropriate concentration to study the effect of metal ions on ethanol fermentation by yeast. Due to contamination, molasses should be treated to reduce metal ions which act as inhibitors during ethanol production. Starchy crops need to undergo hydrolysis to convert the starch 
http://wjst.wu.ac.th

into glucose, and lignocellulosic biomass (bagasse) has to be treated before hydrolysis to alter the cellulose structures for enzyme accessibility [5]. In practice, the optimized yeast culture is 1 factor that directly affects the metabolism of cell growth and the efficiency of ethanol production. Moreover, the most important parameter in ethanol fermentation is ethanol-producing microorganisms. Therefore, it is important to select a highly efficient microbial strain. Many microorganisms can convert sugars into ethanol using their metabolisms, such as bacteria (Zymomonas spp.) and yeast (Schizosaccharomyces spp., Saccharomyces spp. and Candida spp.) that can cleave sugar and use different pathways for sugars utilization such as $S$. cerevisiae hydrolyzing sucrose using enzyme (invertase) which produced by itself during fermentation [6]. It is important to consider the selected yeast properties under harsh conditions such as ethanol tolerance, temperature tolerance, $\mathrm{pH}$ tolerance, or metal ion contamination.

$S$. cerevisiae was selected to produce alcohol and fuel ethanol production due to its sucrose utilization as the nutrient substrate. It has greater ethanol tolerance properties, tolerance to a wide range of $\mathrm{pH}$ and other inhibitory compounds than other ethanol-producing microorganisms [7,8]. Thus, all the optimized parameters previously stated are important to achieve high efficiency of ethanol production. Chandrasena et al. [9], investigated influence of calcium ion concentration, $0.007-0.100 \%(\mathrm{w} / \mathrm{v})$, potassium concentration, $0.200-0.700 \%(\mathrm{w} / \mathrm{v})$ and magnesium concentration, $0.200-0.700 \%(\mathrm{w} / \mathrm{v})$ to ethanol production. It was found that an increase in magnesium ion concentration improved ethanol yield regardless of the amount of calcium ion and potassium ions in the sample. However, in that study, metal ions were in a mixture. There is a potential of synergistic effect between metal ions to ethanol yield and cell yeast. Chotineeranat et al. [10] investigated the influence of calcium ion on ethanol production in a pure system at a wide range of concentrations, $0.000-2.160 \%(\mathrm{w} / \mathrm{v})$. The concentration of calcium ion below $1.440 \%(\mathrm{w} / \mathrm{v})$ did not reduce ethanol production. There is a difference in the effect of calcium ion concentration on ethanol production between this work and Chandrasena's study, supporting the hypothesis of synergistic effect and optimum concentration between metal ions to ethanol yield. AkridaDemertzi et al. [11] investigated the influence of calcium and potassium ion concentration on ethanol fermentation and found that calcium inhibited ethanol yield, similar to other studies. However, potassium ion concentration was found to increase fermentation efficiency when investigated the influence of metal ion individually in the range of $0.050-0.300 \%(\mathrm{w} / \mathrm{v})$. The difference in results was due to the investigation method between a mixture of metal ions and selected metal ion concentration. To the best of our knowledge, a study on the metal ions effect reported an inhibitory effect of a metal ion in the sample. However, there is inconsistency among studies. Therefore, it is necessary to perform a study focusing on each metal ion that can affect ethanol products.

This research investigates the effects of inorganic compounds or metal ions on ethanol production efficiency by $S$. cerevisiae studied in a sucrose solution since it is the primary molasse component. The presence of inorganic compounds or metal ions in the real sugar-based substrates, such as molasses, probably results from fertilizer contamination during cane cultivation or the use of some ions in sugar manufacturing, such as in the clarification process [10]. This research focused on the calcium ion, potassium ion, and magnesium ion as these ions are often found in molasses in substantial quantities [24]. To avoid synergistic effect between metal ions in the sample to ethanol production yield, we constructed an investigation in which single 3 type metal ions were used. Calcium ion, potassium ion, and magnesium ion in the range covering actual concentration were commonly found. Thus, understanding the effects of metal ion contamination on $S$. cerevisiae fermentation kinetics could help develop good practical pretreatment or preparation of molasses as the substrate for the highly efficient production of ethanol. 


\section{Materials and methods}

\section{Material}

Sucrose was supplied by Mitr Phol Sugar Co., Ltd. (Thailand). A commercial dry active yeast, S. cerevisiae, was supplied by Angel Yeast Co., Ltd. (China).

\section{invertase}

Effect of environmental metal ion contamination on yeast fermentation and activity of

\section{S. cerevisiae fermentation}

The control culture medium consisted of $200 \mathrm{~g} / \mathrm{L}$ sucrose supplemented (carbon source). Sucrose is the preferred carbon and energy source for produce ethanol by yeast with $10 \mathrm{~g} / \mathrm{L}$ of yeast extract (nitrogen source). Nitrogen sources in the must are important for yeast metabolism and cell growth. Two concentrations of metal ions $\left(\mathrm{Ca}^{2+}\right.$; in the form of $\mathrm{CaCl}_{2}, \mathrm{~K}^{+}$; in the form of $\mathrm{KCl}$, and $\mathrm{Mg}^{2+}$; in the form of $\mathrm{MgCl}_{2}$ ) were supplemented with 0.20 and $0.60 \%(\mathrm{w} / \mathrm{v})$. The culture medium was adjusted to $\mathrm{pH} 4.5$ before sterilization. S. cerevisiae was cultivated in the culture medium at $32{ }^{\circ} \mathrm{C}$ and $120 \mathrm{rpm}$ for $72 \mathrm{~h}$ in a shaker incubator. The medium samples were collected at $0,2,4,6,10,24,30,48$, 54, and $72 \mathrm{~h}$ for analysis of specific growth rate, substrate consumption, ethanol concentration, glycerol, sucrose, glucose, and fructose contents.

\section{Invertase production by $S$. cerevisiae}

At $10 \mathrm{~h}$ of fermentation time, a medium sample was collected to analyze for invertase activity through centrifugation at $10,000 \mathrm{rpm}$ and $4{ }^{\circ} \mathrm{C}$ for $15 \mathrm{~min}$. After which, the supernatant was collected as crude invertase [8].

\section{Invertase activity assay}

Invertase activity assay followed the method described by Nakamura et.al. [8]. An amount of 1.0 $\mathrm{mL}$ of $0.5 \%(\mathrm{w} / \mathrm{v})$ sucrose in $0.05 \mathrm{M}$ acetate buffer $(\mathrm{pH} 4.5)$ was prepared as the substrate of the reaction, and then $0.5 \mathrm{~mL}$ of crude invertase was added. The mixture was incubated at $32{ }^{\circ} \mathrm{C}$ for 30 min then boiled for $10 \mathrm{~min}$ to stop the reaction. Aliquots were used to quantify the amount of reducing sugar using the Somogyi-Nelson method [12] as the products of enzyme reaction. One unit of invertase activity was defined as the amount of enzyme required to release $1 \mu \mathrm{mol}$ of glucose per minute under assay conditions. Invertase activity was calculated using:

Unit $/ \mathrm{L}=\frac{\text { concentration of glucose }(\mathrm{w} / \mathrm{v}) \times \mathrm{V}_{\mathrm{t}}(\mathrm{mL}) \times 1000 \times \mathrm{df}}{\mathrm{MW} \times \mathrm{V}_{\mathrm{e}}(\mathrm{mL}) \times \mathrm{T}(\mathrm{min})}$

where: $\mathrm{V}_{\mathrm{t}}=$ total volume $(\mathrm{mL}) ; \mathrm{df}=$ dilution factor; $\mathrm{MW}=$ molecular weight of glucose $(\mathrm{g} / \mathrm{mol}) ; \mathrm{V}_{\mathrm{e}}=$ volume of enzyme $(\mathrm{mL})$; and $\mathrm{T}=$ incubation time $(\mathrm{min})$.

\section{Effects of environmental metal ion contamination on ethanol production parameters}

\section{Cell growth}

Cell growth was determined using a hemocytometer to calculate the specific growth rate. The yeast specific growth rate, $\mu\left(\mathrm{h}^{-1}\right)$, was calculated from the slope of the linear dependence of the yeast cell number $(\mathrm{cfu} / \mathrm{mL})$ on the fermentation time of culture media [10]. (HPLC)

Analysis sugar, ethanol and glycerol contents by high performance liquid chromatography

The sugars (sucrose, glucose, and fructose), ethanol, and glycerol contents were determined using HPLC. The chromatographic system consisted of a Water 1,525 binary pump and a differential refractive index detector (RI-150, Japan). A VertiSep ${ }^{\mathrm{TM}}$ Sugar CMP column $\left(7.8 \times 300 \mathrm{~mm}^{2}, 8 \mu \mathrm{m}\right.$; Vertical Chromatography Co., Ltd.) at $80{ }^{\circ} \mathrm{C}$, mobile phase: Deionized water, and the flow rate at $0.40 \mathrm{~mL} / \mathrm{min}$ 
was used to analyze the sugars content. An Aminex HPX-87H (Bio-Rad Laboratories, Inc., USA) at $40{ }^{\circ} \mathrm{C}$, mobile phase: $0.5 \mathrm{mM}$ Sulfuric acid $\left(\mathrm{H}_{2} \mathrm{SO}_{4}\right)$, and the flow rate at $0.60 \mathrm{~mL} / \mathrm{min}$ was used to analyze the ethanol and glycerol concentrations. Throughout the experimental work, data were collected and integrated using the LC solution software (Shimadzu, Japan) [10].

\section{Statistical analysis}

All experiments were performed in duplicate. All results were expressed as mean \pm standard deviation (SD). Analysis of variance (ANOVA) (SPSS-17). Significant difference among the replicates has been presented as Duncan's multiple ranges in the form of probability $(\mathrm{p}<0.05)$ value.

\section{Results and discussion}

Effect of environmental metal ion contamination on $S$. cerevisiae invertase activity

During yeast fermentation, $S$. cerevisiae produces invertase to hydrolyze sucrose molecules into its monosaccharides (glucose and fructose) in the yeast cell's periplasmic space; subsequently, the monosaccharides enter the cell by facilitating the diffusion and approach to the glycolytic pathway $[13,14]$. S. cerevisiae invertase activity that was determined at $10 \mathrm{~h}$ of fermentation time under no metal ion stress (as a control condition) was 1,580 U/L as shown in Table 1. Under the environmental stress of metal ion contamination in the medium, invertase activity was decreased, especially with $\mathrm{Ca}^{2+}$ ion contamination. This showed a significant decline as the ion concentration increased with invertase having an average enzyme activity value of 1,257 and $972 \mathrm{U} / \mathrm{L}$ at 0.20 and $0.60 \%(\mathrm{w} / \mathrm{v})$ of $\mathrm{Ca}^{2+}$ ion concentration, respectively, which was much greater decrease than other ions. At $0.20 \%(\mathrm{w} / \mathrm{v}) \mathrm{K}^{+}$and $\mathrm{Mg}^{2+}$ ion concentrations, an average invertase activity decreased to 1,437 and $1,473 \mathrm{U} / \mathrm{L}$, respectively. When ions concentration increased to $0.60 \%(\mathrm{w} / \mathrm{v})$, there was a significant decrease of activity in the presence of $\mathrm{K}^{+}$compared with the control, while the increased $\mathrm{Mg}^{2+}$ ion contamination slightly changed activity. The severe stress of metal ion contamination on invertase was distinguishable in the following order: $\mathrm{Ca}^{2+}>\mathrm{K}^{+}>\mathrm{Mg}^{2+}$, especially at the higher metal ion concentration of $0.60 \%(\mathrm{w} / \mathrm{v})$.

Table 1 Effect of metal ions on invertase activity of $S$. cerevisiae fermentation at $10 \mathrm{~h}$.

\begin{tabular}{cccc}
\hline \multirow{2}{*}{ Metal ion } & \multicolumn{2}{c}{ Invertase activity (U/L) } \\
\cline { 2 - 4 } & \multirow{2}{*}{ Control } & \multicolumn{2}{c}{ Metal ion concentration } \\
\cline { 2 - 4 } & $1,580 \pm 0.00^{\mathrm{a}, \mathrm{A}}$ & $\mathbf{0 . 2 0} \% \mathbf{( w / v )}$ & $\mathbf{0 . 6 0} \% \mathbf{( w / v )}$ \\
\hline $\mathrm{Ca}^{2+}$ & $1,257 \pm 35.92^{\mathrm{b}, \mathrm{B}}$ & $972 \pm 35.92^{\mathrm{c}, \mathrm{C}}$ \\
$\mathrm{K}^{+}$ & $1,580 \pm 0.00^{\mathrm{a}, \mathrm{A}}$ & $1,437 \pm 71.84^{\mathrm{ab}, \mathrm{A}}$ & $1,293 \pm 71.84^{\mathrm{b}, \mathrm{B}}$ \\
$\mathrm{Mg}^{2+}$ & $1,580 \pm 0.00^{\mathrm{a}, \mathrm{A}}$ & $1,473 \pm 35.92^{\mathrm{ab}, \mathrm{A}}$ & $1,437 \pm 71.84^{\mathrm{b}, \mathrm{A}}$ \\
\hline
\end{tabular}

${ }^{\mathrm{a}, \mathrm{b}, \mathrm{c}}$ Mean within the same row different letters and significant difference $(p<0.05)$

${ }^{\mathrm{A}, \mathrm{B}, \mathrm{C}}$ Mean within the same column different letters and significant difference $(p<0.05)$

Sugar utilization in $\boldsymbol{S}$. cerevisiae fermentation under environmental stresses of metal ions

Metal ions acted as inhibitors on invertase that resulted in the declined of the enzyme activity and resulted in sugar consumption, as shown in Figure 1. Normally, sugars utilization during yeast fermentation starts with sucrose being hydrolyzed by invertase into glucose and fructose, which become available for carbon sources cell metabolism. Under no stresses of metal ion contamination (control), sucrose was hydrolyzed rapidly together with sharply increased glucose and fructose levels during the 1st $10 \mathrm{~h}$ of fermentation. After that, sucrose was slightly decreased then was finally depleted at $24 \mathrm{~h}$, while its monosaccharides rapidly decreased with glucose depletion being faster than for fructose after $10 \mathrm{~h}$. Both monosaccharides (glucose and fructose) had been depleted at $48 \mathrm{~h}$ of fermentation time. As with the previous results (Table 1), contaminated metal ions in the culture medium inhibited invertase activity that 
resulted in problems with sucrose conversion and hence reduced sucrose utilization and the consumption of glucose and fructose of yeast cells.

Consequently, there were high levels of remaining sugars in the culture medium (Figure 1). The stress from $\mathrm{Ca}^{2+}$ contamination produced significantly severe effects on sugar consumption because it was a potent inhibitor. The mechanism of $\mathrm{Ca}^{2+}$ ion inhibition on invertase activity through sucrose hydrolysis follows the competitive inhibition. The inhibitor competes with the substrate for the active site of the enzyme [15]. The inhibitor will combine reversibly with the enzyme to form an enzyme-inhibitor complex which can reduce the amount of enzyme for interaction with the substrate. Therefore, the reaction rate decrease. $\mathrm{Ca}^{2+}$ ion in the sucrose hydrolysis system by invertase decreases reducing sugar (glucose and fructose) production. The $\mathrm{Ca}^{2+}$ ion inhibited the invertase activity. It can be seen from the decrease of reducing sugar production over sucrose. The higher the $\mathrm{Ca}^{2+}$ ion concentration in the culture medium, the lower the reduction of sugar produced and sugar consumption, which was a much greater decrease than $\mathrm{K}^{+}$and $\mathrm{Mg}^{2+}$ ion, respectively.

(a) Calcium ion $\left(\mathrm{Ca}^{2+}\right)$
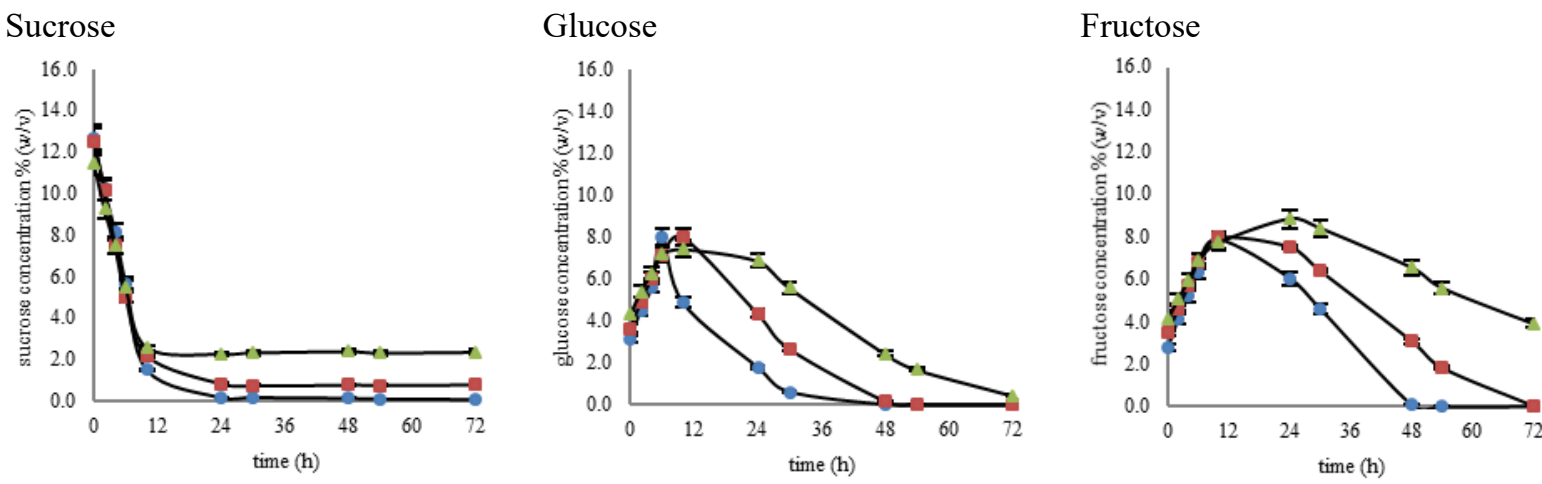

(b) Potassium ion $\left(\mathrm{K}^{+}\right)$

Sucrose

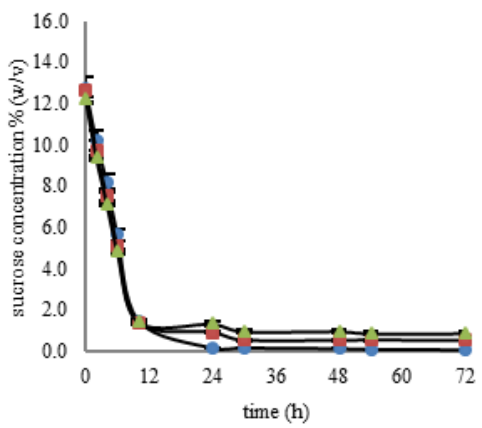

Glucose

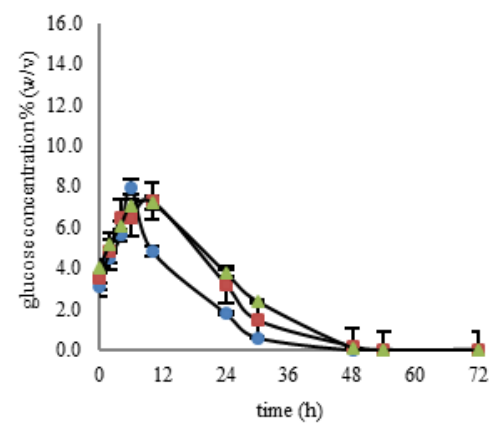

Fructose

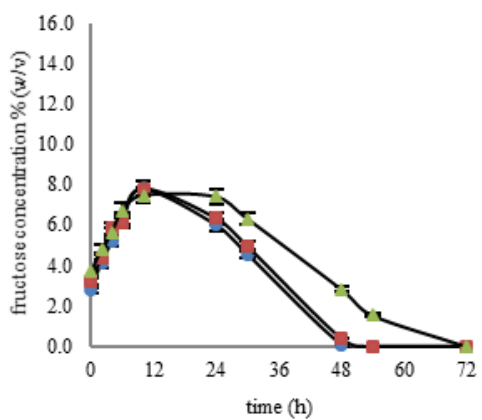


(c) Magnesium ion $\left(\mathrm{Mg}^{2+}\right)$
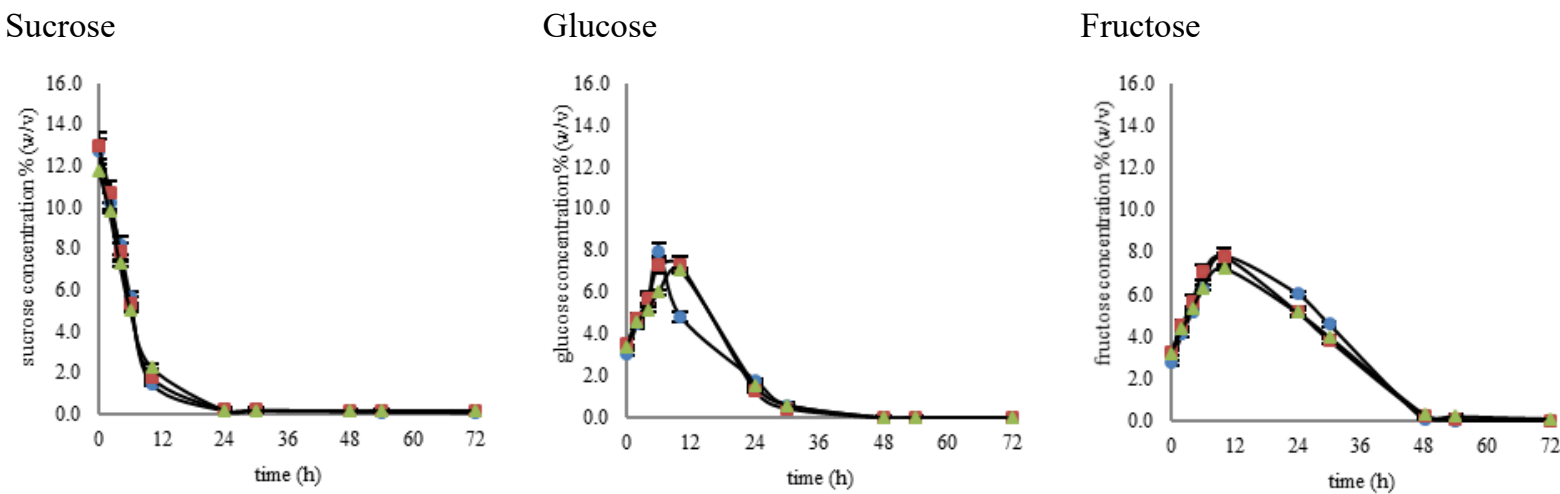

Figure 1 Concentrations of sugars (sucrose, glucose, and fructose) during $S$. cerevisiae fermentation under metal ion contamination with: (a) calcium ion; $\mathrm{Ca}^{2+}$, (b) potassium ion; $\mathrm{K}^{+}$, and (c) magnesium ion; $\mathrm{Mg}^{2+}$ at different ion concentrations where $\bullet$ control, $\mathbf{\square} 0.20 \%(\mathrm{w} / \mathrm{v})$, and $\boldsymbol{\Delta} 0.60 \%(\mathrm{w} / \mathrm{v})$.

\section{Effects of environmental metal ion contamination on ethanol production parameters \\ Cell growth, specific growth rate, and substrate consumption}

The decreased invertase activity inhibited by metal ion contamination caused less sucrose hydrolysis, which subsequently affects cell metabolism such as cell growth, specific growth rate, substrate consumption, and ethanol production, including secondary metabolisms glycerol production. The effects of metal ion contamination on yeast fermentation are shown in Table 2. The specific growth rate and substrate consumption under no metal ion contamination were $0.21 \mathrm{~h}^{-1}$ and $4.63 \mathrm{~g} / \mathrm{L} / \mathrm{h}$, respectively. When metal ions contaminated the yeast medium, there was a clear stress effect on cell metabolism and declines in cell growth (Table 2 and Figure 2) and substrate consumption (Table 2). The stress of $\mathrm{Ca}^{2+}$ ion significantly decreased both the specific growth rate and substrate consumption that was clear at the low concentration, $0.20 \%(\mathrm{w} / \mathrm{v})$ and became more severe when the $\mathrm{Ca}^{2+}$ ion concentration increased. Costa et al. [16] reported that a calcium concentration of more than $0.12 \%(\mathrm{w} / \mathrm{v})$ decreased the number of live cells during the fermentation process, which was in agreement with the results shown in Figure 2. The $\mathrm{K}^{+}$ion significantly decreased the sucrose consumption and specific growth rate at both ion concentrations $(0.20$ and $0.60 \%(\mathrm{w} / \mathrm{v}))$, while the $\mathrm{Mg}^{2+}$ ion significantly decreased both parameters only at $0.60 \%(\mathrm{w} / \mathrm{v})$. In contrast, at $0.20 \%(\mathrm{w} / \mathrm{v})$ of $\mathrm{Mg}^{2+}$ ion concentration, the substrate consumption slightly increased, but cell growth slightly declined (Table 2).

Table 2 Specific growth rate, substrate consumption and ethanol concentration of $S$. cerevisiae fermentation under $\mathrm{Ca}^{2+}, \mathrm{K}^{+}$, and $\mathrm{Mg}^{2+}$ contamination.

\begin{tabular}{|c|c|c|c|c|c|c|c|c|c|}
\hline \multirow{3}{*}{ Metal ion } & \multicolumn{9}{|c|}{ Parameters } \\
\hline & \multicolumn{3}{|c|}{ Specific growth rate $\left(h^{-1}\right)^{*}$} & \multicolumn{3}{|c|}{ Substrate consumption $(\mathrm{g} / \mathrm{L} / \mathrm{h})^{* *}$} & \multicolumn{3}{|c|}{ Ethanol concentration $(\% \mathrm{w} / \mathrm{v})^{* * *}$} \\
\hline & Control & $0.20 \%(w / v)$ & $0.60 \%(w / v)$ & Control & $0.20 \%(w / v)$ & $0.60 \%(w / v)$ & Control & $0.20 \%(w / v)$ & $0.60 \%(w / v)$ \\
\hline $\mathrm{Ca}^{2+}$ & $0.21 \pm 0.01^{\mathrm{a}, \mathrm{A}}$ & $0.11 \pm 0.00^{\mathrm{b}, \mathrm{C}}$ & $0.08 \pm 0.01^{\mathrm{b}, \mathrm{C}}$ & $4.63 \pm 0.10^{\mathrm{a}, \mathrm{A}}$ & $3.70 \pm 0.03^{\mathrm{b}, \mathrm{C}}$ & $1.76 \pm 0.01^{\mathrm{c}, \mathrm{C}}$ & $9.37 \pm 0.09^{\mathrm{a}, \mathrm{A}}$ & $7.18 \pm 0.00^{\mathrm{b}, \mathrm{C}}$ & $2.95 \pm 0.08^{\mathrm{c}, \mathrm{B}}$ \\
\hline $\mathrm{K}^{+}$ & $0.21 \pm 0.01^{\mathrm{a}, \mathrm{A}}$ & $0.17 \pm 0.02^{\mathrm{bc}, \mathrm{B}}$ & $0.16 \pm 0.02^{\mathrm{c}, \mathrm{B}}$ & $4.63 \pm 0.10^{\mathrm{a}, \mathrm{A}}$ & $4.11 \pm 0.03^{\mathrm{ab}, \mathrm{B}}$ & $3.66 \pm 0.06^{\mathrm{b}, \mathrm{B}}$ & $9.37 \pm 0.09^{\mathrm{a}, \mathrm{A}}$ & $8.96 \pm 0.05^{\mathrm{a}, \mathrm{B}}$ & $6.80 \pm 0.78^{\mathrm{b}, \mathrm{A}}$ \\
\hline $\mathrm{Mg}^{2+}$ & $0.21 \pm 0.01^{\mathrm{a}, \mathrm{A}}$ & $0.19 \pm 0.00^{\mathrm{ab}, \mathrm{A}}$ & $0.17 \pm 0.01^{\mathrm{b}, \mathrm{A}}$ & $4.63 \pm 0.10^{\mathrm{a}, \mathrm{A}}$ & $4.80 \pm 0.17^{\mathrm{a}, \mathrm{A}}$ & $4.33 \pm 0.09^{\mathrm{b}, \mathrm{A}}$ & $9.37 \pm 0.09^{\mathrm{a}, \mathrm{A}}$ & $9.35 \pm 0.19^{\mathrm{a}, \mathrm{A}}$ & $6.81 \pm 0.11^{\mathrm{b}, \mathrm{A}}$ \\
\hline
\end{tabular}

${ }^{a, b, c}$ Mean within the same row different letters and significant difference $(p<0.05)$

${ }^{\mathrm{A}, \mathrm{B}, \mathrm{C}}$ Mean within the same column different letters and significant difference $(p<0.05)$

${ }^{*}$ Specific growth rate at $0-10 \mathrm{~h}{ }^{* *}$ Substrate consumption at $6-48 \mathrm{~h}{ }^{* * *}$ Ethanol concentration at $48 \mathrm{~h}$ 
(a) Calcium ion $\left(\mathrm{Ca}^{2+}\right)$

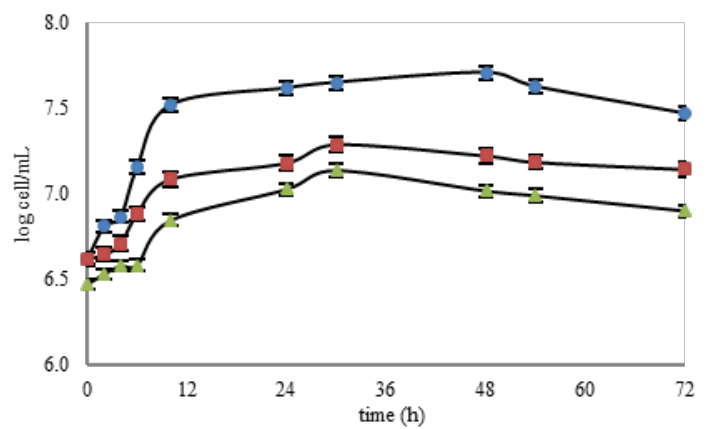

(c) Magnesium ion $\left(\mathrm{Mg}^{2+}\right)$

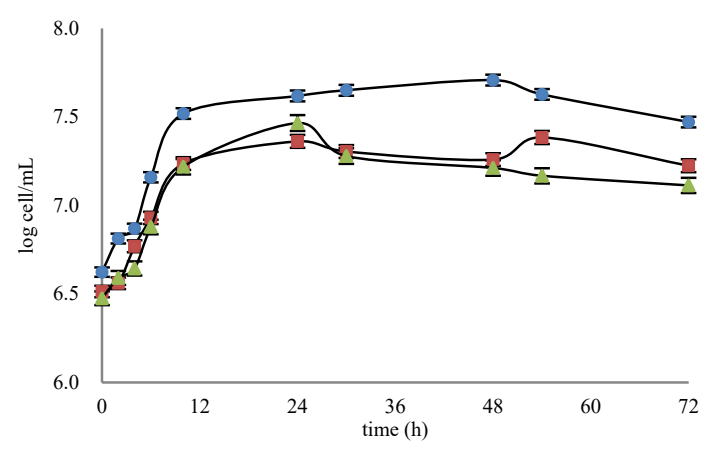

(b) Potassium ion $\left(\mathrm{K}^{+}\right)$

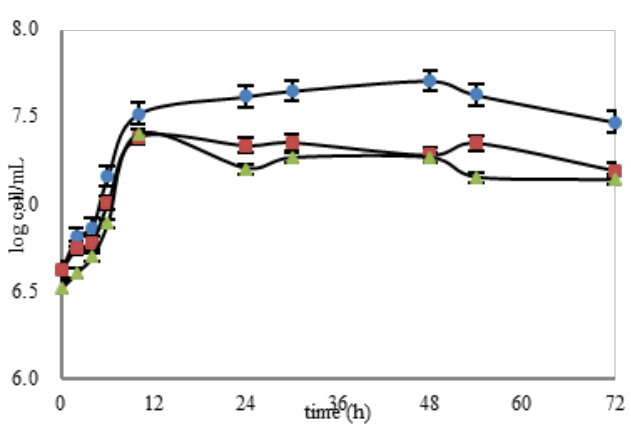

Figure 2 S. cerevisiae growth under metal ion stress during ethanol fermentation: (a) $\mathrm{Ca}^{2+}$; (b) $\mathrm{K}^{+}$; and (c) $\mathrm{Mg}^{2+}$ at different ion concentrations where $\bullet$ control, $0.20 \%(\mathrm{w} / \mathrm{v})$, and $\boldsymbol{\Delta} 0.60 \%(\mathrm{w} / \mathrm{v})$.

\section{Primary and secondary production during S. cerevisiae fermentation: Ethanol and glycerol production}

In addition to the contaminated metal ions in the medium causing decreased invertase activity and cell metabolism, the production of the product, ethanol, and by-product, glycerol fluctuated under this stress condition as shown in Figures $\mathbf{3}$ and $\mathbf{4}$, respectively. The efficiency of ethanol production decreased when the culture medium was contaminated with metal ions. The $\mathrm{Ca}^{2+}$ ion clearly and significantly decreased ethanol production starting at the lower ion concentration of $0.20 \%(\mathrm{w} / \mathrm{v})$, while $\mathrm{K}^{+}$and $\mathrm{Mg}^{2+}$ ion showed a significant decline at $0.60 \%(\mathrm{w} / \mathrm{v})$ compared with the control.

In fact, glycerol is one of the by-products from yeast ethanol fermentation, like carbon dioxide, lactic acid, etc. The important function of glycerol synthesis in yeast cells is related to redox balancing and the hyperosmotic stress response [17]. The contamination of metal ions in the medium is one type of hyperosmotic stress on the yeast cell. The challenge for $S$. cerevisiae was to develop a mechanism for surviving the hyperosmotic stress by accumulation or increasing intracellular osmolality, mainly of glycerol for osmotic adjustment $[18,19]$.

Of interest, under normal conditions of fermentation (control), the yeast produced ethanol together with a slight increase in glycerol production. When the ethanol production increased sharply after $10 \mathrm{~h}$ $(10-24 \mathrm{~h})$ of yeast fermentation, glycerol was also produced continuously until $24 \mathrm{~h}$ of fermentation. When glucose utilization was nearly completed between 24 - $30 \mathrm{~h}$ (Figure 1), glycerol production sharply and significantly increased, while ethanol production continued at a constant rate. After $30 \mathrm{~h}, S$. cerevisiae produced glycerol at a constant rate. At the same time, ethanol production sharply and 
significantly increased again after the yeast cells had adapted to the changed conditions, and yeast cells fermented ethanol until the sugars had been completely used up, indicating yeast's completion fermentation. Therefore, the results showed a significant increase in glycerol production due to the yeast cell adapting through the optimized and changed conditions, while ethanol continued to be produced at a constant rate throughout (Figures 1, 3 and 4). Besides changing substrate utilization, the high stress of metal ion contamination resulted in greater production of glycerol. To assist in cell survival of the hyperosmotic stress during fermentation, as evidenced by the $\mathrm{Ca}^{2+}$ and $\mathrm{K}^{+}$ion contamination, there was a significant increase in glycerol production, especially at the higher ion concentration, which was negatively related to the flux-diffusion at the cell membrane. However, this was less affected by $\mathrm{Mg}^{2+}$ contamination. In the case of metal ions contaminated in culture medium such as molasses, we had recommended that pretreatment molasses by acid before fermentation were then introduced to remove metal ions which improved the fermentation efficiency.

(a) Calcium ion $\left(\mathrm{Ca}^{2+}\right)$

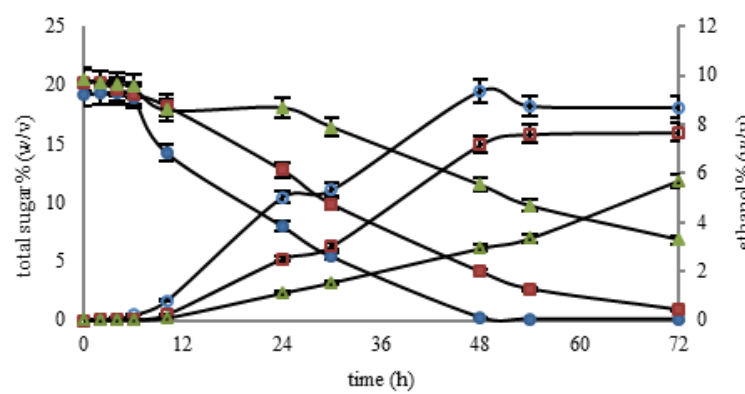

(c) Magnesium ion $\left(\mathrm{Mg}^{2+}\right)$

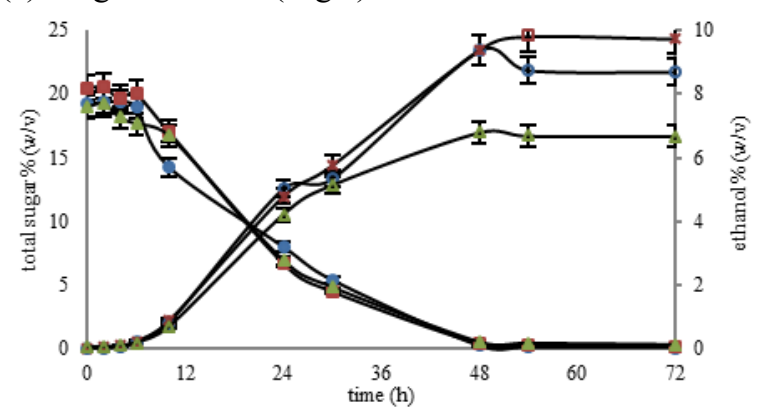

(b) Potassium ion $\left(\mathrm{K}^{+}\right)$

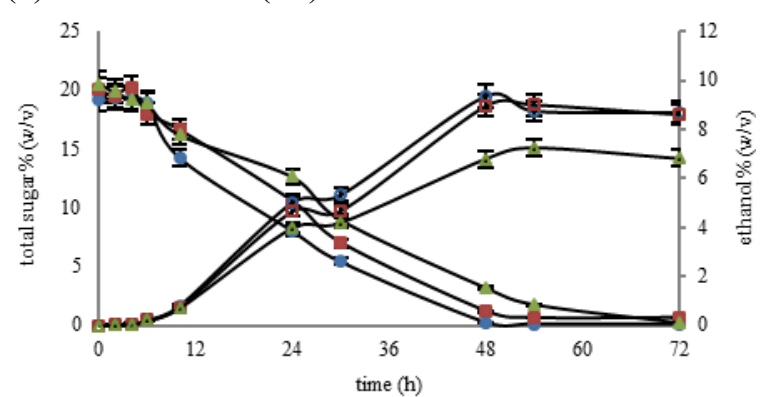

Figure 3 Total sugar concentration and ethanol production during $S$. cerevisiae fermentation under metal ion contamination: (a) calcium ion, $\mathrm{Ca}^{2+}$; (b) potassium ion, $\mathrm{K}^{+}$; and (c) magnesium ion, $\mathrm{Mg}^{2+}$ at different ion concentrations, where total sugar utilization: $\bullet$ control, $0.20 \%(\mathrm{w} / \mathrm{v})$, and $\boldsymbol{\Delta} 0.60 \%(\mathrm{w} / \mathrm{v})$; and ethanol concentration: $\circ$ control, $\square 0.20 \%(\mathrm{w} / \mathrm{v})$, and $\Delta 0.60 \%(\mathrm{w} / \mathrm{v})$. 


\section{(a) Calcium ion $\left(\mathrm{Ca}^{2+}\right)$}

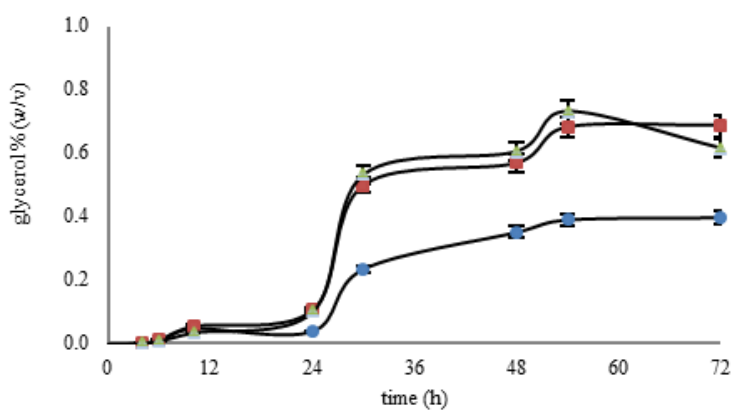

(c) Magnesium ion $\left(\mathrm{Mg}^{2+}\right)$

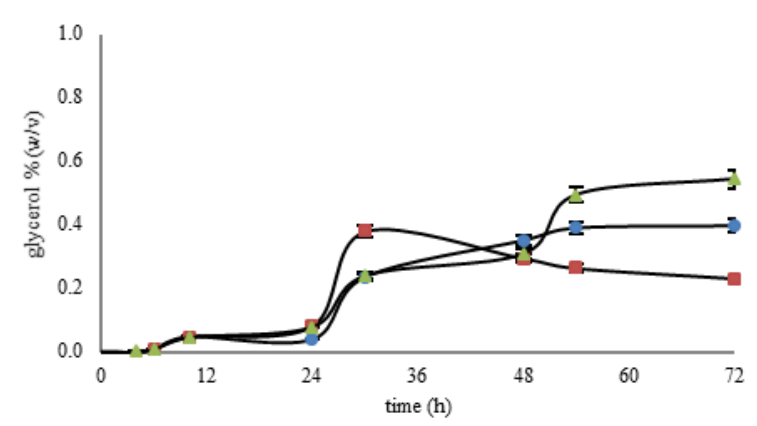

(b) Potassium ion $\left(\mathrm{K}^{+}\right)$

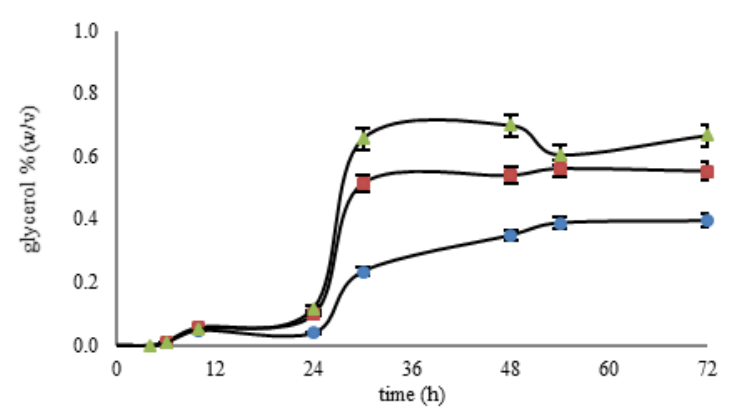

Figure 4 Glycerol production during S. cerevisiae fermentation under metal ion contamination; (a) calcium ion; $\mathrm{Ca}^{2+}$, (b) potassium ion; $\mathrm{K}^{+}$, and (c) magnesium ion; $\mathrm{Mg}^{2+}$ at different ions concentration where $\bullet$ control, $0.20 \%(\mathrm{w} / \mathrm{v})$ and $\boldsymbol{\Lambda} 0.60 \%(\mathrm{w} / \mathrm{v})$.

\section{Conclusions}

The stress-induced contamination of all metal ions had significant effects on ethanol production as the decreased invertase activity resulted in inhibited sugar consumption and subsequently affected the cell metabolism of S. cerevisiae, including low efficiency of ethanol production. In contrast, this increased the amount of glycerol which was not a targeted product in ethanol production. The $\mathrm{Ca}^{2+}$ ion acted as a harsher inhibitor of ethanol production than the other ions, especially at the higher concentration of ion contamination.

\section{Acknowledgements}

The authors wish to express their gratitude to the Thailand Research Fund (TRF). This work was financially supported with contract number RDG 61T0068 for "Effects of metal ions contamination in molasses on ethanol production of Saccharomyces cerevisiae". The authors declare that they have no conflict of interest. 


\section{References}

[1] LC Basso, TO Basso and SN Rocha. Ethanol production in Brazil: The industrial process and its impact on yeast fermentation. In: MADS Bernardes (Ed.). Biofuell production-recent developments and prospects. In Tech, Rijeka, Croatia. 2011, p. 85-100.

[2] MA Clarke. Syrup. Encyclopedia Food Sci. Nutr. 2003; 2, 5711-7.

[3] Y Yilmaz, I Celik and F Isik. Mineral composition and total phenolic content of pomegranate molasses. J. Food Agr. Environ. 2007; 4, 102-4.

[4] JR Wythes, DH Wainwright and GW Blight. Nutrient composition of Queensland molasses. Aust. J. Exp. Agr. Anim. Husbandry 1978; 18, 629-34.

[5] H Zabed, JN Sahu, A Suely, AN Boyce and G Faruq. Bioethanol production from renewable sources: Current perspectives and technological progress. Renew. Sustain. Energ. Rev. 2017; 71, 475-501.

[6] A Tesfaw and F Assefa. Current trends in bioethanol production by Saccharomyces Cerevisiae: Substrate, inhibitor reduction, growth variables, coculture, and immobilization. Int. Sch. Res. Notices 2014; 2014, 532852.

[7] MK Somda, A Savadogo, CAT Ouattara, AS Ouattara and AS Traore. Improvement of bioethanol production using amylasic properties from Bacillus Licheniformis and yeasts strains fermentation for biomass valorization. Asian J. Biotechnol. 2011; 3, 254-61.

[8] K Nakamura, SI Kondo, Y Kawai, N Nakajima and A Ohno. Amino acid sequence and characterization of aldo-keto reductase from bakers' yeast. Biosci. Biotechnol. Biochem. 1997; 61, 375-7.

[9] G Chandrasena, GM Walker and HJ Staines. Use of response surfaces to investigate metal ion interactions in yeast fermentations. J. American Soc. Brew. Chemist. 1997; 55, 24-9.

[10] S Chotineeranat, R Wansuksri, K Piyachomkwan, P Chatakanonda, P Weerathaworn and K Sriroth. Effect of calcium ions on ethanol production from molasses by Saccharomyces cerevisiae. Sugar Tech. 2010; 2, 120-4.

[11] K Akrida-Demertzi and AA Koutinas. Optimization of sucrose etanol fermentation for $\mathrm{K}, \mathrm{Na}, \mathrm{Ca}$, and $\mathrm{Cu}$ metal contents. Appl. Biochem. Biotechnol. 1991; 30, 1-7.

[12] M Somogyi. Notes on sugar determination. J. Biol. Chem. 1952; 195, 19-23.

[13] W Marques, AK Gombert, V Raghavendran and BU Stambuk. Sucrose and Saccharomyces cerevisiae: A relationship most sweet. FEMS Yeast Res. 2016; 16, 107.

[14] KK Essel and YD Osei. Investigation of some kinetic properties of commercial invertase from yeast. Nat. Prod. Chem. Res. 2014; 2, 1000152.

[15] M Whidden, A Ho, M Ivanova and S Schnell. Competitive inhibition reaction mechanisms for the two-step model of protein aggregation. Biophys. Chem. 2014; 193-194, 9-19.

[16] GHG Costa, RC Messias, EDV Lozano, LC Nogueira and LM Blanco. The effect of calcium concentration on the physiology of Saccharomyces cerevisiae yeast in fermentation. Sugar Tech. 2018; 20, 371-4.

[17] S Hohmann. Osmotic stress signaling and osmoadaptation in yeasts. Microbiol. Mol. Biol. Rev. 2002; 66, 300-72.

[18] KT Scanes, S Hohrnann and BA Prior. Glycerol production by the yeast Saccharomyces cerevisiae and its relevance to wine: A review. S. Afr. J. Enol. Viticulture 1998; 19, 17-24.

[19] S Shabala and L Shabala. Ion transport and osmotic adjustment in plants and bacteria. Biomol. Concepts 2011; 5, 407-19. 